\title{
EVALUATION OF INTRA- AND INTER-OBSERVER AGREEMENT OF ULTRASONOGRAPHIC FINDINGS AFTER ADIPOSE TISSUE DERIVED MESENCHYMAL STEM CELLS TREATMENT OF SUPERFICIAL DIGITAL FLEXOR TENDON INJURIES IN HORSES
}

Marcello Giovanni Sala ${ }^{1}$, Fernando Canonici ${ }^{2}$, Katia Barbaro ${ }^{1}$, Elisabetta Aquilini ${ }^{3}$, Andrea Carvelli ${ }^{1 *}$, Valentina Spallucci ${ }^{1}$, Maria Teresa Scicluna ${ }^{1}$

${ }^{1}$ Istituto Zooprofilattico Sperimentale del Lazio e della Toscana "M. Aleandri", Via Appia Nuova 1411, 00178 Roma, ${ }^{2}$ Clinica Veterinaria Equine Practice, Strada Valle del Baccano, 80, 00063 Campagnano di Roma, ${ }^{3}$ sstituto Nazionale di Statistica (ISTAT), via Cesare Balbo 16, 00184 Roma, Italy

*Corresponding author, E-mail: andrea.carvelli@izslt.it

\begin{abstract}
The present paper assesses the multi-observer evaluation of ultrasonographic response of horses with superficial digital flexor tendon (SDFT) damage to the inoculation of autologous adipose mesenchymal stem cells (AMSCs). The study included 15 horses recruited at an equine hospital following a SDFT damage diagnosis. Horses were implanted with AMSCs obtained from the paracaudal region. Treatment efficacy, in terms of morphological recovery of SDTF considered as degree of echogenicity (TS) and percentage of fibres alignment (FAS), was evaluated using four experts. Inter-observer agreement of experts' judgements on ultrasonographic examinations in different stages of recovery was calculated. The classification of the intra-observer agreement was defined as good for both TS and FAS while the inter-observer agreement was good for TS and moderate for FAS. Ultrasonographic images judged as having a higher TS showed 95 times greater chance of belonging to the final recovery stage than the first and a 50 times greater chance resulted for FAS. This study provided evidence that the interobserver agreement of ultrasonographic images is a reliable and valid method to evaluate the morphological recovery of injured tendons. In addition, the study demonstrated the morphological recovery of SDFT in horses following AMSCs injection through an independent evaluation system.
\end{abstract}

Key words: multi-observer agreement; ultrasonographic diagnosis; adipose mesenchymal stem cells; equine tendon desmopathy.

\section{Introoduction}

Myo-tendinopathies are common pathological conditions affecting the musculoskeletal system of the horse. The competitive career of sport horses may be shortened because of tendon injuries, especially because full recovery is extremely difficult or impossible. Although several medical and surgical treatments have been proposed over the past years, nowadays, there is a growing interest in the use of stem cells for the recovery of

Received: 26 February 2019

Accepted for publication: 30 September 2019 injured tendons as an alternative to the traditional approach. Many papers report the treatment of equine tendinopathies with bone marrow derived mesenchymal stem cells (BMDSC) and their healing is reported by histological, immunohistochemical findings and clinical observations $(1,2)$. Follow-up studies confirm the success of this treatment and the functional recovery of racehorses with injuries of the Superficial Digital Flexor Tendon (SDFT) following treatment with BMDSC (3-5). In addition, in the last decades the presence of mesenchymal multilineage stem cells in adipose tissue has been widely documented (6), as well as the multipotency characteristic of the 
Adipose Mesenchymal Stem Cells (AMSCs) $(7,8)$. The adipose tissue can represent a more suitable substrate in terms of isolation, expansion rate and number of cells available for the implant when compared with BMDSC because of the higher amount of stromal cells present (9). Many authors confirmed the potential benefit of regenerative therapy using adipose-derived nucleated cells in improving equine tendon injuries (10-13).

Ultrasonography diagnosis has been proved useful in the assessment of the equine tendon recovery after stem cell implantation, especially from a qualitative point of view, because of the early detection of tendon fibres regeneration. Nevertheless, clinical trials based on the use of ultrasonographic diagnosis for the evaluation of the efficacy of such approach have not been conducted so far.

The aim of this paper is to assess intra- and inter-observer agreement of the ultrasonographic evaluation of damaged SDFT healing after the inoculation of autologous AMSCs.

\section{Materials and methods}

\section{Cases selection}

The study was a prospective case series design. During 2008 and 2009, 15 horses were recruited with a total of 17 acute superficial digital flexor tendinopathies, -7 racehorses, 6 thoroughbred and 1 trotter) and 8 performance horses $(6$ show jumpers, 1 eventing and 1 quarter horse). Horses with a SDFT lesion were enrolled in the course of routine clinical practice. The 15 horses included in the study had 17 SDFT lesions of different severity. According to the quantitative ultrasonographic assessment proposed by Genovese et al. (14) 3 lesions scored a Severity Rate (SR) of III, 1 scored a SR of IV, 7 scored a SR of V and 6 scored a SR of VI. The research protocol was submitted and approved by the Italian Ministry of Health and its Animal Welfare Unit (RC LT 02/07).

\section{AMSC procedure}

Horses were implanted with autologous AMSCs according to the Regulations regarding the use of heterologous cellular and biological products $(15$, 16). Before starting the study, tests to determine the multipotency characteristics of the horse's
AMSC were carried out through the in vivo and in vitro induction for cell differentiation in the presence of lineage-specific induction factors (17).

In previous trials carried out, authors observed that cells survived in fat at $4^{\circ} \mathrm{C}$ more than 5 days after collection, as well as after cell splitting and harvesting, but with a moderate, diminishing yield. To reduce this variability, delivery of tissue samples from the equine hospital to the laboratory and vice-versa was established to be less than two hours.

During the study, AMSCs were extracted from the subcutaneous adipose tissue that had been surgically collected from the paracaudal region of each horse, under sedation and local anaesthesia. Following collection, a variable amount of adipose tissue sample (5-20 g), depending on the individual fat abundance at the sampling site, was dipped in a vessel containing an antibiotic (100 $\mathrm{U} / \mathrm{mL}$ penicillin and $100 \mathrm{mg} / \mathrm{mL}$ streptomycin), $0,1 \mathrm{M}$ phosphate-buffered saline solution and transported to the laboratory. The isolation and the expansion of cells were performed from the stromal fraction of adipose tissue (6). After shaving and disinfection of the leg with povidoneiodine and alcohol, the expanded cells were injected into SDFT lesion under ultrasonographic control. A variable number of cells, ranging from 0.5 to $2.5^{*} 10^{6}$, were injected, depending on the concentration of the cells obtained during the expansion. Most of the cases were treated with 1 $\mathrm{ml}$. One case was injected with $2 \mathrm{ml}$ because of the extent of the lesion. The injection was performed using a 20 gauge needle within two hours following their re-suspension in $1 \mathrm{ml}$ of autologous plasma, approximately 7 days after their collection, during the subacute phase.

\section{Ultrasonographic diagnosis}

All horses were examined using the same ultrasonographic protocol. Ultrasonographic examinations were performed 7-10 days before the injection of stem cells (stage A), that corresponded to the day of surgical adipose tissue collection, 60 days (stage B) and 120 days after the injection (stage C). All horses were examined by the same operator using the same ultrasonographic equipment with a standard procedure in terms of preparation of the leg, probe frequency $(10 \mathrm{MHz})$, gain and focus regulation. 


\section{Evaluation of the SDTF morphological recovery}

Tendon morphological recovery after the injection of stem cells was evaluated through the measurement of the intra- and inter-observer agreement of judgement on ultrasonographic findings performed by 4 veterinarians, internationally recognized as experts in diagnostic imaging. For this purpose, 3 ultrasonographic exams were collected from each of the 17 damaged tendons at stage A, $\mathrm{B}$ and $\mathrm{C}$ respectively, counting up a set of $51 \mathrm{im}-$ ages. Experts received a DVD containing the same set repeated 3 times $(51 \times 3=153$ images in total) and 2 tables in a purposely developed spreadsheet. In each table, all 153 images were listed and each image was identified by a unique alphanumeric code to assure blind assessment. In addition, the experts were not aware that the set of 153 images was actually made up of 3 repeats of each of the 51 ultrasound scans.

Experts were required to give 2 types of judgement for each ultrasonographic examination: the degree of echogenicity (TS) and the percentage of fibres alignment observed (FAS), according to an ordinal scale of 4 categories: completely anechoic (CA), mostly anechoic (MA), hypoechoic (HP), isoechoic (IS) for TS and 0-25\% (AN), 26-50\% (LO), $51-75 \%$ (MD), $76-100 \%$ (HY) of fibres observed for FAS. Before evaluating ultrasonographic images, experts were requested to have an agreement relative to the different mentioned categories corresponding to those reported in figure 1 .

\section{Data analysis}

The 4 categories of judgement concerning both the degree of echogenicity and the percentage of fibres alignment observed were arbitrarily defined and not outlined by formal specifications. The border between the categories was not clear-cut and the experts might have been affected by a certain degree of subjectivity, thus representing a potential for misclassification. For this reason, TS and FAS were recoded into dichotomous variables:

- recoded TS: "Low" (CA or MA) and "high" (HP or IS) degree of echogenicity;

- recoded FAS: "Moderate" (AN or LO) and "abundant" (MD or HY) percentage of fibres alignment observed.

The Cohen's kappa coefficient $(\mathrm{k})(18,19)$, as further implemented (20) and adapted (21), was chosen to evaluate the intra- and inter-observer agreement beyond chance of judgement given on each ultrasonographic image by the single expert and by the entire group of experts, respectively. The same method was then applied to evaluate the intra- and inter-observer agreement of judgements given on ultrasonographic images at the same stage of the lesion (A, B, C). The classification proposed by Landis and Koch (22) was applied for interpreting $\mathrm{k}$ : values above 0.61 indicate substantial agreement beyond chance.

The same data were also analysed using a multivariable logistic regression to objectively assess the anatomic recovery following the injection of stem cells.
Figure 1: Ultrasonography- Cross Sectional Area (CSA) occupied by the lesion. Examples of degree of echogenicity score (TS) and fiber alignment score (FAS): A = isoechogenic (IS) - fiber 75-100\% (HY); B = hypoechogenic (HP) - fiber 50-75\% (MD); C = mostly anechogenic (MA)- fiber 25-50\% (LO); $\mathrm{D}=$ completely anechogenic $(\mathrm{CA})-$ fiber $0-25 \%$ (AN)
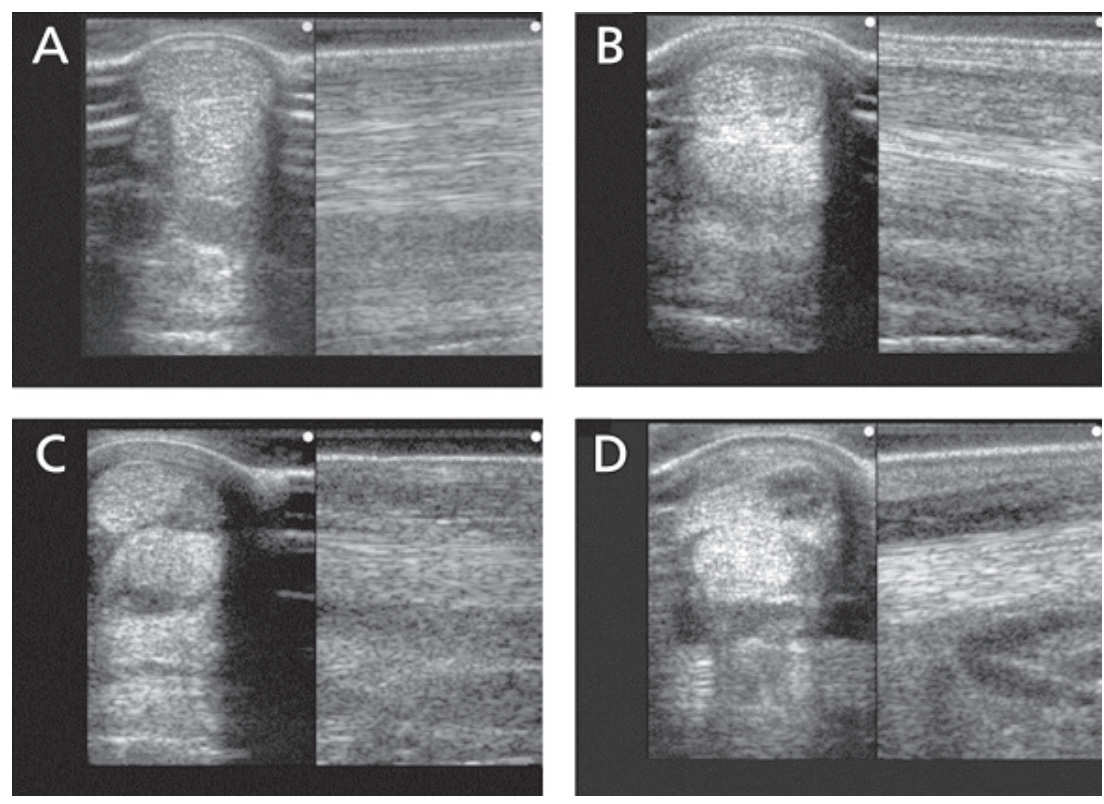
The probability that a judgement of high TS and FAS was given to ultrasonographic exams at stage $\mathrm{B}$ or $\mathrm{C}$ compared to images at stage A was also calculated. In detail, the judgements on the recoded TS (high/low) and recoded FAS observed (moderate/abundant) were chosen as outcome variables, while the stage of lesion $(\mathrm{A}, \mathrm{B}, \mathrm{C})$, the duplication sets $\left(1^{\text {st }}, 2^{\text {nd }}, 3^{\text {rd }}\right)$ and the expert $(1,2$, $3,4)$ as explanatory variables. Odds ratio (OR) and 95\% confidence interval (CI 95\%) were estimated. The analyses were performed using the software Stata (23).

\section{Clinical evaluation}

Following the cell inoculation, the horses were confined in stalls for 2 weeks. Hand walking for 6 weeks was prescribed starting from the third week, during this time the first ultrasonographic control was suggested, before starting a light exercise consisting of walking and trotting increased every 2 weeks up to twentieth week. At that time, if the healing process was satisfactory, the exercise was further increased to racing or competition training, which was started after the thirtieth - thirtysecond week depending on the stage of the healing process, assessed through ultrasonographic examination. An ultrasonographic control was recommended every 8 weeks throughout the whole rehabilitation program.

The clinical results, regarding the recovery of their previous athletic activity, were evaluated through the official data for the racehorses and by collecting direct information from the owners in case of the performance horses. For racehorses, to have raced at least four times after treatment was considered as a positive outcome. Any reoccurrence of the SDFT lesion was recorded during the follow-up.

\section{Ethical statement}

Clinical procedures described in the present paper did not require approval from an ethics committee. Nevertheless, procedures were performed in accordance with guidelines set by the Committee for Research and Ethical Issues of IASP.

\section{Results}

The cell cultures were ready for inoculation about 7 days after adipose tissue collection. In the absence of standardised indications relative to the cell/dose inoculum, even if with a shelf life lasting more than 2 days (personal observations), a variable number of cells ranging from 500,000 to $2,500,000$ per horse was injected within 2 hours following their re-suspension in $1 \mathrm{ml}$ of autologous plasma.

In addition, to ensure a low differentiation degree from the first isolation no more than 2 cell passages were made. The number of cells was related to age (faster growth in younger animals) and to the amount of adipose tissue collected, not always abundantly available. After the injection of AMSCs into the SDFT, no local inflammatory reaction reported by the ultrasonographic control.

The total number of judgements given by the 4 experts amounted to 1,224. Each expert gave 306 judgements: 153 on the TS and 153 on the FAS observed.

A preliminary descriptive analysis of data showed a tendency of experts to assign a judgment of higher TS and greater FAS to ultrasound scans performed at stage $B$ and stage $C$ rather than those being performed at stage A (Table 1).

According to the Landis and Koch's table (22), the overall intra-observer agreement of each expert-i.e. the agreement between the judgements given by the same expert on the 3 duplications of the same ultrasonographic image - was classified at least "good" for both judgements, on TS and on FAS, because of k-values always rating higher than 0.61 (Table 2).

As a further evidence of the good level of selfconsistency of judgements given by the same expert, the intra-observer agreement of each expert increased when breaking down the judgements by stage of lesion. The overall inter-observer agreement - i.e. the agreement between all experts' judgements given on the same ultrasonographic image - was "good" for judgements on TS $(\mathrm{k}=0.71)$, but only "moderate" for those on FAS $(\mathrm{k}=0.58)$. Breaking down the experts' judgements by stage of lesion, the inter-observer agreement was 
Table 1: Degree of echogenicity (TS) and Percentage of Fibres Observed (FAS). Distribution of the judgments given by each expert by stage of lesion (17 ultrasonographic exams in each stage $=51.51 * 3$ repetition $=153$ judgements per expert in total)

\begin{tabular}{|c|c|c|c|c|c|c|c|c|c|}
\hline & & \multirow[b]{2}{*}{ Categories } & \multirow{2}{*}{$\begin{array}{l}\text { Recoded } \\
\text { catego- } \\
\text { ries }\end{array}$} & \multicolumn{3}{|c|}{ Judgements } & \multirow{2}{*}{$\begin{array}{c}\text { Total } \\
\text { judgements } \\
\text { per } \\
\text { categories }\end{array}$} & \multirow{2}{*}{$\begin{array}{l}\text { Total } \\
\text { judgements } \\
\text { per recoded } \\
\text { categories }\end{array}$} & \multirow[b]{2}{*}{$\begin{array}{l}\text { Expert total } \\
\text { judgements }\end{array}$} \\
\hline & & & & $\begin{array}{c}\text { Stage } \\
\mathbf{A}\end{array}$ & $\begin{array}{c}\text { Stage } \\
\text { B }\end{array}$ & $\begin{array}{c}\text { Stage } \\
\text { C }\end{array}$ & & & \\
\hline \multirow{16}{*}{ TS } & \multirow{4}{*}{$\begin{array}{c}\text { Expert } \\
1\end{array}$} & $\mathbf{C A}$ & \multirow{2}{*}{ Low } & 14 & 0 & 0 & 14 & \multirow{2}{*}{49} & \multirow{4}{*}{153} \\
\hline & & MA & & 27 & 8 & 0 & 35 & & \\
\hline & & HP & \multirow{2}{*}{ High } & 10 & 20 & 33 & 63 & \multirow{2}{*}{104} & \\
\hline & & IS & & 0 & 23 & 18 & 41 & & \\
\hline & \multirow{4}{*}{$\begin{array}{c}\text { Expert } \\
2\end{array}$} & $\mathbf{C A}$ & \multirow{2}{*}{ Low } & 13 & 0 & 0 & 13 & \multirow{2}{*}{43} & \multirow{4}{*}{153} \\
\hline & & MA & & 21 & 7 & 2 & 30 & & \\
\hline & & $\mathrm{HP}$ & \multirow{2}{*}{ High } & 17 & 27 & 30 & 74 & \multirow{2}{*}{110} & \\
\hline & & IS & & 0 & 17 & 19 & 36 & & \\
\hline & \multirow{4}{*}{$\begin{array}{c}\text { Expert } \\
3\end{array}$} & $\mathbf{C A}$ & \multirow{2}{*}{ Low } & 15 & 3 & 0 & 18 & \multirow{2}{*}{55} & \multirow{4}{*}{153} \\
\hline & & MA & & 27 & 5 & 5 & 37 & & \\
\hline & & HP & \multirow{2}{*}{ High } & 9 & 15 & 17 & 41 & \multirow{2}{*}{98} & \\
\hline & & IS & & 0 & 28 & 29 & 57 & & \\
\hline & \multirow{4}{*}{$\begin{array}{c}\text { Expert } \\
4\end{array}$} & $\mathbf{C A}$ & \multirow{2}{*}{ Low } & 17 & 0 & 0 & 17 & 18 & \\
\hline & & MA & & 21 & 10 & 0 & 31 & 40 & 152 \\
\hline & & $\mathbf{H P}$ & High & 8 & 11 & 24 & 43 & 105 & 103 \\
\hline & & IS & High & 5 & 30 & 27 & 62 & 105 & \\
\hline & & AN & Moderato & 13 & 0 & 0 & 13 & 30 & \\
\hline & Expert & LO & Moderate & 21 & 5 & 0 & 26 & 39 & 152 \\
\hline & 1 & MD & Abundont & 15 & 14 & 25 & 54 & 114 & 153 \\
\hline & & HY & ADundant & 2 & 32 & 26 & 60 & 114 & \\
\hline & & AN & Modorote & 34 & 5 & 2 & 41 & 60 & \\
\hline & & LO & Moderate & 8 & 9 & 10 & 27 & 08 & 152 \\
\hline & Expert & MD & Ahundant & 9 & 12 & 23 & 44 & 85 & 153 \\
\hline FAS & & $\mathbf{H Y}$ & ADundant & 0 & 25 & 16 & 41 & 85 & \\
\hline FAS & & AN & Mederate & 19 & 3 & 0 & 22 & 56 & \\
\hline & Expert & LO & Moderate & 25 & 5 & 4 & 34 & 50 & \\
\hline & 3 & MD & 11 & 7 & 19 & 22 & 48 & & 153 \\
\hline & & $\mathbf{H Y}$ & Abundant & 0 & 24 & 25 & 49 & 97 & \\
\hline & & AN & Mederote & 17 & 0 & 0 & 17 & 51 & \\
\hline & Expert & LO & Moderate & 23 & 10 & 1 & 34 & 51 & 152 \\
\hline & 4 & MD & Ahindant & 5 & 9 & 21 & 35 & 100 & 153 \\
\hline & & $\mathbf{H Y}$ & ADundant & 6 & 32 & 29 & 67 & 102 & \\
\hline
\end{tabular}

* AN= 0-25\%, LO=26-50\%, MD=51-75\%, HY=76-100\%; CA: Completely Anechoic; MA: Mostly Anechoic; HP: Hypoechoic; IS: Isoechoic 
Table 2: Intra-observer agreement by stage of lesion and overall intra-observer agreement (k-value) reached by each expert on judgements given on recoded TS and on recoded FAS by stage of lesion

\begin{tabular}{cccc|cccc}
\hline \multicolumn{3}{c|}{ Recoded TS categories } & \multicolumn{4}{c}{ Recoded FAS categories } \\
\hline Stage A & Stage B & Stage C & TS Overall & Stage A & Stage B & Stage C & FAS Overall \\
\hline 0.92 & 0.92 & 1 & 0.95 & 0.92 & 0.92 & 1 & 0.95 \\
0.76 & 0.76 & 0.92 & 0.82 & 0.76 & 0.76 & 0.92 & 0.74 \\
0.69 & 0.84 & 0.76 & 0.76 & 0.69 & 0.84 & 0.76 & 0.76 \\
0.88 & 0.84 & 1 & 0.87 & 0.88 & 0.84 & 1 & 0.87 \\
\hline
\end{tabular}

"good" for both the types of judgement only for ultrasonographic images taken at stage $\mathrm{B}$ and $\mathrm{C}$ (TS $\mathrm{k}=0.81$ and $\mathrm{k}=0.88$, FAS $\mathrm{k}=0.64$ and $\mathrm{k}=0.84$ respectively). Nevertheless, the inter-observer agreement was "moderate" for judgements on ultrasound scans taken at stage A (TS, $k=0.44$; FAS, $\mathrm{k}=0.42$ ).

The logistic regression model confirmed that the probability to assign a judgement of "high" echogenicity and "abundant" percentage of fibres alignment observed to ultrasonographic images taken at stage $\mathrm{B}$ or $\mathrm{C}$ was actually greater than the probability to assign the same judgements to those taken at the stage A. In detail, ultrasonographic images judged as being "high" echogenic have shown 95 times greater chance of being one of those actually taken at stage C $(O R=95.8$; CI 95\%: 41.8-219.5) than being one of those taken at stage A. In addition, ultrasonographic images judged as having an "abundant" percentage of fibres have shown 50 times greater chance of being one of those actually taken at stage $\mathrm{C}(\mathrm{OR}=49.5$, CI 95\%: 26.3-93.1) than being one of those taken at stage A.

Table 3. Multivariate logistic regressions: effect of stage of lesion, duplication and expert on the recoded TS and FAS categories

\begin{tabular}{|c|c|c|c|c|c|c|}
\hline \multirow[t]{2}{*}{ Outcome } & \multicolumn{2}{|c|}{ Explanatory variables } & \multirow{2}{*}{$\begin{array}{l}\mathbf{O R}^{*} \\
1.00\end{array}$} & \multirow{2}{*}{$\frac{\text { p value }}{-}$} & \multicolumn{2}{|c|}{$95 \%$ confidence interval } \\
\hline & \multirow{3}{*}{ Stage of lesion } & A & & & - & - \\
\hline \multirow{9}{*}{$T S$} & & B & $17.42 \dagger$ & 0.00 & 10.53 & 28.84 \\
\hline & & $\mathrm{C}$ & $95.85 \dagger$ & 0.00 & 41.84 & 219.54 \\
\hline & \multirow{3}{*}{ Duplication } & $1^{\text {st }}$ & 1.00 & - & - & - \\
\hline & & $2^{\text {nd }}$ & 0.96 & 0.89 & 0.54 & 1.69 \\
\hline & & $3^{\text {rd }}$ & 1.53 & 0.15 & 0.86 & 2.73 \\
\hline & \multirow{4}{*}{ Expert } & 1 & 1.00 & - & - & - \\
\hline & & 2 & 1.41 & 0.31 & 0.73 & 2.75 \\
\hline & & 3 & 0.72 & 0.32 & 0.37 & 1.38 \\
\hline & & 4 & 1.06 & 0.87 & 0.55 & 2.05 \\
\hline \multirow{10}{*}{ FAS } & \multirow{3}{*}{ Stage of lesion } & A & 1 & - & - & - \\
\hline & & B & $19.72 \dagger$ & 0.00 & 11.70 & 33.24 \\
\hline & & $\mathrm{C}$ & $49.46 \dagger$ & 0.00 & 26.28 & 93.08 \\
\hline & \multirow{3}{*}{ Duplication } & $1^{\text {st }}$ & 1.00 & - & - & - \\
\hline & & $2^{\text {nd }}$ & 1.04 & 0.89 & 0.60 & 1.79 \\
\hline & & $3^{\text {rd }}$ & 1.32 & 0.33 & 0.76 & 2.28 \\
\hline & \multirow{4}{*}{ Expert } & 1 & 1.00 & - & - & - \\
\hline & & 2 & $0.22 \dagger$ & 0.00 & 0.11 & 0.43 \\
\hline & & 3 & $0.39 \dagger$ & 0.01 & 0.20 & 0.76 \\
\hline & & 4 & 0.51 & 0.05 & 0.26 & 0.99 \\
\hline
\end{tabular}

*OR: Odds Ratio; $\uparrow: p<0.001$ 
The multivariable analysis excluded - regarding those judgements on TS - any effect related to the experts' subjectivity and the repetition of the ultrasonographic images on the observed outcome, i.e. the ability to systematically select a judgement of high echogenicity to ultrasonographic images taken at later stages (Table 3). Nevertheless, regarding those judgements on FAS, a protective effect of the experts' subjectivity (especially expert 2 and 3) was observed on the outcome. This does not affect the overall tendency to systematically select a judgement of "high" echogenicity to ultrasonographic images taken at later stages (Table 3).

Furthermore, the follow-up of treated horses revealed a good level of recovery. In the racehorses group, 5 out of $7(71 \%)$ horses raced at least 4 times after treatment, while 6 out of $8(75 \%)$ performance horses recovered their previous athletic activity.

\section{Discussion}

In the absence of a standardised cell/dose inoculum and taking in consideration the time consuming procedure needed to obtain constant concentrations of cells coming from different samples, the timeliness of inoculation was privileged in order to preserve as much as possible the cells viability. As therapeutic success is influenced by the time elapsing from injuries to cell administration (5), fibrosis and scar tissue formation affect healing, the restriction of this interval period was preferred to the cell inoculum standardisation. In addition, this procedure also reduce the number of cells passages and therefore maintain their original multipotency characteristics. In some cases, to reach concentrations of many millions of cells, at least one more week would have been necessary, compromising the time interval between injury and therapy. Other authors have already shown the difficulty in establishing a significant difference between re-injury rate and amount of cells injected (3).

The collection of fat from paracaudal region has been demonstrated in being an easy and safe procedure in obtaining an appropriate sample for AMSCs culture even if more invasive than collection from the sternum bone marrow, procedure fatal complications.
In the present study the therapeutic success or injury reoccurrence do not seem to be associated to the concentrations of the cells inoculum nor the horse age.

Regarding the re-injury rates observed in this study $(29 \%$ in racehorses and $25 \%$ in other competition horses), these are lower than what reported when using a medical approach (24) and similar to those described in another longer term follow-up (3), carried out after implantation of BMSC, $27 \%$ and $25 \%$ in race and National Hunting horses, respectively, re-injured.

The no completely satisfactory results of inter-observer agreement may be due to ultrasonographic exams taken at stage A (initial lesions) which could have been more difficult to evaluate for having different degrees of echogenicity and fibres damage, thus, leaving the opportunity of assigning the images of stage A to more classes than those in later stages. In addition, it can not be excluded that judgments on the same ultrasonographic exam might have been affected by a systematic error derived from different factors such as the expert's subjectivity and the technical features of the screens used to display the images. Neverthless, the statistical analysis has shown clear intra- and inter-observer agreement of the judgments.

Even if the study did not enrol a homogeneous cohort of horses regarding age, gender, breed and intended use, the statistical results indicated a significant agreement between the 4 experts. This finding indicates an objective association between ultrasonographic images taken at stage B or C and the judgements of "high" echogenicity and "abundant" percentage of fibres observed, providing evidence of the substantial morphological recovery of the tendon's damage in all the horses subjected to autologous AMSCs inoculation.

The present study provided evidence that the inter-observer agreement of ultrasonographic findings is a reliable and valid method to evaluate the morphological recovery of injured tendons. In addition, the present study also demonstrated the morphological recovery of SDFT in horses following the injection of AMSCs through an independent evaluation system. 


\section{References}

1. Crovace A, Lacitignola L, Rossi G, et al. Histological and immunohistochemical evaluation of autologous cultured bone marrow mesenchymal stem cells and bone marrow mononucleated cells in collagenase-induced tendinitis of equine superficial digital flexor tendon. Vet Med Int 2010; 2010: e250978.

2. Schnabel LV, Lynch ME, van der Meulen $\mathrm{MC}$, et al. Mesenchymal stem cells and insulinlike growth factor-I gene-enhanced mesenchymal stem cells improve structural aspects of healing in equine flexor digitorum superficialis tendons. $J$ Orthop Res 2009; 27: 1392-8.

3. Godwin EE, Young NJ, Dudhia J, et al. Implantation of bone marrow-derived mesenchymal stem cells demonstrates improved outcome in horses with overstrain injury of the superficial digital flexor tendon. Equine Vet J 2011; 26: 1-9.

4. Pacini S, Spinabella S, Trombi L, et al. Suspension of bone marrow-derived undifferentiated mesenchymal stromal cells for repair of superficial digital flexor tendon in race horses. Tissue Eng 2007; 13: 2949-55.

5. Smith RK. Mesenchymal stem cell therapy for equine tendinopathy. Disabil Rehabil 2008; 30: 1752-8.

6. Zuk PA, Zhu M, Mizuno H, et al. Multilineage cells from human adipose tissue: implications for cell-based therapies. Tissue Eng 2001; 7: 211-28.

7. Ashjian PH, Elbarbary AS, Edmonds B, et al. In vitro differentiation of human processed lipoaspirate cells into early neural progenitors. Plast Reconstr Surg 2003; 111: 1922-31.

8. Helder M, Knippenberg M, Klein-Nulend J, et al. Stem cells from adipose tissue challenging new concepts for regenerative medicine. Tissue Eng 2007; 13: 1799-808.

9. Nakagami H, Morishita R, Maeda K, et al. Adipose tissue-derived stromal cells as a novel option for regenerative cell therapy. J Atheroscler Thromb 2006; 13: 77-81.

10. Arnhold S, Wenisch S. Adipose tissue derived mesenchymal stem cells for musculoskeletal repair in veterinary medicine. Am J Stem Cells 2015; 4: 1-12.

11. Chong AK, Chang J, Go JC. Mesenchymal stem cells and tendon healing. Front Biosci 2009; 14: 4598-605.

12. Nixon AJ, Dahlgren LA, Haupt JL, et al. Effect of adipose-derived nucleated cell fractions on tendon repair in horses with collagenase-induced tendinitis. Am J Vet Res 2008; 69: 928-37.

13. Richardson LE, Dudhia J, Clegg PD, et al. Stem cells in veterinary medicine-attempts at regenerating equine tendon after injury. Trends Biotechnol 2007; 25: 409-16.

14. Genovese R, Longo K, Berthold B, et al. Quantitative sonographic assessment in the clinical management of superficial digital flexor injuries in Thoroughbred racehorses. In: Proceedings of $43^{\text {rd }}$ Annual Convention of the American Association Equine Practitioners. Phoenix, Arizona, 1997: 285-90.

15. Norbert KM. The regulation of veterinary regenerative medicine and the potential impact of such regulation on clinicians and firms commercializing these treatments. Vet Clin North Am Equine Pract 2001; 27: 383-91.

16. Yingling GL, Nobert KM. Regulatory considerations related to stem cell treatment in horses. J Am Vet Med Assoc 2008; 232: 1657-61.

17. Amaddeo D, Canonici F, Barbaro K, et al. Fat derived stem cells platelet gel associated in arthroscopy treatment of a subchondral cyst of the medial femoral condyle of a horse. In: Proceedings of the 14th SIVE/FEEVA Congress. Lido di Venezia, 2008: 353-54.

18. Cohen J. A coefficient of agreement for nominal scales. Educ Psychol Meas 1960; 20: 37-46.

19. Cohen J. Weighted kappa: nominal scale agreement with provision for scaled dis-agreement or partial credit. Psychol Bull 1968; 70: 213-20.

20. Fleiss JL, Levin B, Paik MC. The measurement of interrater agreement. In: Statistical methods for rates and proportions. $3^{\text {rd }}$ ed. New York : John Wiley \& Sons, 2003: 598-626.

21. Randolph JJ. Free-marginal multi-rater kappa: an alternative to Fleiss's fixed-marginal multi-rater kappa. In: Proceedings of Joensuu University Learning and Instruction Symposium, Joensuu, 2005.

22. Landis JR, Koch GG. The measurement of observer agreement for categorical data. Biometrics 1977; 331: 159-74.

23. Stata ${ }^{\circledR}$ user's guide. StataCorp 2012; 1: 47.

24. Dyson SJ. Medical management of superficial digital flexor tendonitis: a comparative study in 219 horses 1992-2000. Equine Vet J 2004; 36: 415-9. 


\title{
PRESOJA OCEN OPAZOVANJA VEČ STROKOVNJAKOV IN VEČKRATNIH PREGLEDOV ULTRAZVOČNIH UGOTOVITEV PO ZDRAVLJENJU POŠKODBE POVRŠINSKE UPOGIBOVALKE PRSTOV PRI KONJIH Z MEZENHIMSKIMI MATIČNIMI CELICAMI, PRIDOBLJENIMI IZ MAŠČOBNEGA TKIVA
}

\author{
M. G. Sala, F. Canonici, K. Barbaro, E. Aquilini, A. Carvelli, V. Spallucci, M. T. Scicluna
}

Povzetek: Včlanku so obravnavane ocene opazovanj več opazovalcev, ki so z ultrazvokom spremljali celjenje poškodovane tetive površinske upogibovalke prstov (SDFT) po zdravljenju z avtolognimi maščobnih matičnimi celicami (AMSC). V raziskavo je bilo vključenih 15 konjev, ki so bili napoteni na Kliniko za zdravstveno varstvo kopitarjev po diagnozi poškodbe SDFT. Konji so bili zdravljeni z vsadki AMSC, pridobljenimi iz parakavdalnega področja. Učinkovitost zdravljenja v smislu morfološke obnove SDTF, ki je bila obravnavana kot stopnja ehogenosti (TS) in odstotka poravnave vlaken (FAS), je bila ovrednotena s pomočjo štirih strokovnjakov. Izračunana je bila klasifikacija ocen strokovnjakov o opazovanju izsledkov ultrazvočnih pregledov v različnih fazah okrevanja živali. Razvrstitev ocen znotraj posameznega opazovalca je bila značilno enotna za TS in FAS, medtem ko je bila podobnost ocen med opazovalci značilno enotna za TS in zmerno enotna za FAS. Ultrazvočne slike, za katere je bilo ocenjeno, da imajo višjo TS, so pokazale 95-krat večjo možnost za doseganje končne faze okrevanja in 50-krat večjo možnost za FAS. Ta študija dokazuje, da je enotnost ocen, ki izhaja iz ocen ultrazvočnih slik več neodvisnih ocenjevalcev zanesljiva in uporabna metoda za oceno morfološke ozdravitve poškodovanih tetiv. Poleg tega je študija s pomočjo opisanega neodvisnega sistema ocenjevanja pokazala morfološko okrevanje SDFT pri konjih po aplikaciji AMSC.

Ključne besede: dogovor ocenjevanja več opazovalcev; ultrazvočna diagnoza; mezenhimske maščobne matične celice; dezmopatija tetive konjev 